AperTO - Archivio Istituzionale Open Access dell'Università di Torino

\title{
Categorial shift and morphological differentiation
}

\section{This is a pre print version of the following article:}

Original Citation:

Availability:

This version is available http://hdl.handle.net/2318/1693942

since 2019-05-04T09:26:31Z

Published version:

DOI:10.1016/j.langsci.2018.08.010

Terms of use:

Open Access

Anyone can freely access the full text of works made available as "Open Access". Works made available under a Creative Commons license can be used according to the terms and conditions of said license. Use of all other works requires consent of the right holder (author or publisher) if not exempted from copyright protection by the applicable law. 


\section{Categorial shift and morphological differentiation is}

\section{Livio Gaeta}

Department of Humanistic Studies, University of Turin, Italy

A R T I C L E IN F O

Article history:

Available online $\mathrm{xxx}$

\section{A B S T R A C T}

Morphological differentiation is defined as the development of morphological variants which can be considered by speakers to shape the transition to a new, different category. After discussing different cases of morphological differentiation, the paper will focus on the accompanying changes that facilitate the process of category formation. This reflects an active Principle of Maximal Differentiation, which helps speakers distinguish the units belonging to the new categories from the others.

(C) 2018 .

\section{Introduction}

Morphological differentiation can be understood as the development of morphological variants that may (help) shape the transition to (or, the creation of) a new, different category. This process of category formation is accompanied by a number of changes that facilitate the identification of the new category and that can therefore be said to help establish maximal differentiation from the source category. In particular, I will show that in cases where a new category emerges, new morphological traits can be seen to develop that help the speakers distinguish the units belonging to the new category from the units in the source category. Note, however, that the new units will not necessarily encode the differentiation: it is also possible that it is the old units that will be differentiated with regard to the new ones. In this sense, the speakers exploit the information occurring in the speech signal to optimize the process of category formation at a systemic level, taking into account all available options.

The paper is structured as follows: in Section 2, morphological differentiation will be briefly introduced while in Section 3 an active principle of morphological differentiation will be presented and discussed on the basis of the development of the German demonstrative and relative pronoun der; the final Section 4 draws a conclusion.

\section{The issue of morphological differentiation}

\subsection{What is morphological differentiation?}

Morphological differentiation can be regarded as a case of linguistic variation which results from the development of morphological variants of a lexeme that cannot be reduced to a phonological or to a morphophonological alternation. An often-quoted example of morphological differentiation is the English plural pair brothers/brethren, which results from the extension of

\footnotetext{
Parts of this paper were presented on in November 2015 at Freie Universität of Berlin in response to a kind invitation of the Interdisciplinary Center European Languages, within the framework of the Dahlem Lectures in Linguistics on Grammar, Cognition \& Language Change, and in March 2017 at the workshop on "Sprachliche Kodierungs-Asymmetrien, Gebrauchsfrequenz und Informativität" held during the 39th Annual Conference of the Deutsche Gesellschaft für Sprachwissenschaft (DGfS) in Saarbrücken. I am very grateful to all people present there, and especially Martin Haspelmath, Matthias Hüning, Horst Simon and Heide Wegener, as well as Hubert Cuyckens, Stefan Hartmann, and one anonymous reviewer for insightful remarks and suggestions.

Email address: livio.gaeta@unito.it (L. Gaeta)
} 
the $s$-plural to the original $n$-class to which brother used to belong. ${ }^{1}$ The change is captured by Kuryłowicz' fourth law of analogy (see Kuryłowicz, 1947; Hock, 1991, pp. 223-227 for a discussion), according to which the new form takes over the primary function while the old form retains a secondary function exhibiting a specialized meaning.

\begin{tabular}{|c|c|c|c|}
\hline (1) & $\begin{array}{l}\text { Stage I: } \\
\text { Stage II: }\end{array}$ & $\begin{array}{l}<\mathrm{X}-\mathrm{a}>\leftrightarrow|\mathrm{X}-\mathrm{a}|: \\
<\mathrm{X}-\mathrm{b}>\leftrightarrow|\mathrm{X}-\mathrm{a}|: \\
<\mathrm{X}-\mathrm{a}>\leftrightarrow\left|\mathrm{X}-\mathrm{c}_{\mathrm{a}}\right|:\end{array}$ & $\begin{array}{l}<\text { brethr-en }>\leftrightarrow \mid \text { brother-PL } \mid \\
<\text { brother }-\mathrm{s}>\leftrightarrow \mid \text { brother-PL } \mid \\
<\text { brethr-en }>\leftrightarrow \mid \text { brother-PL.COMM } \mid\end{array}$ \\
\hline
\end{tabular}

The example of brother is similar to many other instances of inflectional class changes in which a lexeme that used to belong to an inflectional class that has become unproductive develops inflectional features of a productive inflectional class and finally becomes a member of that class (as, for instance, to fare/fore $>$ to fare/fared, etc.). However, the peculiar character of brother/brethren lies in the fact that here morphological differentiation can be said to have led to lexical differentiation in that one might question whether the plural brethren corresponds to the same lexeme whose plural form is now brothers. One argument in support of lexical differentiation is that the form brethren (and its singular brother) is gender-neutral in that it simply identifies the members of a community, while the kinship term brother is opposed to the feminine sister. Accordingly, we might distinguish between brother $_{1}$ and brother $_{2}$, each with its own semantic and morphological properties.

The question might be considered marginal in English because only a couple of words display an en-plural, namely children and oxen, and these do not show the morphological differentiation of brethren. Furthermore, the en-class is clearly recessive insofar as nouns that used to belong to that class now have the dominant s-plural; these nouns are been, eyen, hosen, housen, kine, kneen, shoon, sistren, treen. Finally, the few new nouns that belong to the domain of computer science, such as boxen, Unixen, $V A X e n$ are clearly formed by analogy with oxen. ${ }^{2}$

\subsection{Morphological differentiation and category formation}

The effects of Kuryłowicz' fourth law are not necessarily confined to situations in which an old suffix is deemed unproductive and subsequently replaced by a more productive one. For instance, in the case of the German noun Mann 'man', the default plural form Männer coexists with the semantically more specific plural form Mannen 'vassals, henchmen'; the suffix -en, as in Mannen, is especially found with masculine nouns designating (superior) males: Mensch 'person'/Menschen; Professor 'professor'/Professoren; Hase 'hare'/Hasen; Affe 'monkey'/Affen, etc. (see Gaeta, 2008 for an overview). However, the case of Mann does not constitute a single, isolated instance of lexical differentiation, as does brother, but it is one of several instances of plural doublets that might be seen as giving rise to the formation of a new category. Table 1 lists all German masculine or neuter nouns displaying the er-plural alongside a second plural (mostly formed with the most productive suffix -e, more seldom with -en or zero).

Apparently, the set contained in the table is not random, but obeys a certain rationale that has already been pointed out by Hermann Paul (1917, pp. 27-28):

"Bei einigen Wörtern stehen Plurale mit und ohne -er gleichwertig nebeneinander. Dabei hat sich in der Regel eine Differenzierung eingestellt. Im allgemeinen kann man bemerken, da $\beta$ die Formen ohne -er mehr der feierlichen Sprache angehören, und da $\beta$ in den Formen mit -er der P1.-Begriff schärfer hervortritt. Bande ist = „Fesseln“ im eigentlichen und übertragenen Sinne (Bande der Freundschaft) und wird niemals mit Zahlenbezeichnungen verbunden, sonst lautet der P1. Bänder. Lu[ther] hat nur Bande. Lande ist feierlicher als Länder und wird auch nicht leicht mit Zahlenbestimmungen verbunden". ${ }^{3}$

Paul lists a number of differences that are shared by the two different plural forms: besides a diaphasic difference in that the $e$-plural characterizes more formal ('feierlich') registers, the doublets show a clear semantic difference. The er-plural has a sort of individualizing or 'granular' value that emphasizes the plural nature of the noun more distinctly and which can be easily combined with numerals; in contrast, the $e$-plural favors a more abstract and 'holistic' interpretation. Accordingly, the different plurals may be more, or less, compatible with numerical expressions (see Table 2).

\footnotetext{
${ }^{1}$ In its turn, the nasal inflection of brother was a Middle English innovation - which also testifies of the past productivity of this class - with respect to the zero plural brōpor occurring in Old English (cf. Lass, 1994, p. 136).

${ }^{2}$ On the other hand, the question of lexical differentiation systematically arises whenever morphological differentiation is observed. While no lexical differentiation is likely to be assumed when no semantic differences can be observed between older and newer forms - for instance between a verb to fare 1 /fared

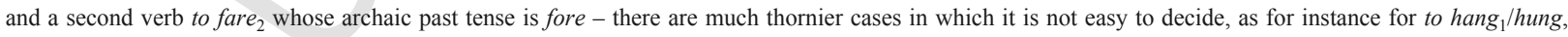
which might be opposed to to hang 2 /hanged.

${ }^{3}$ With certain words plurals with and without $-e r$ occur side by side, with an equivalent value. As a rule, however, a differentiation has occurred. In general, it can be observed that the forms with -er rather belong to ceremonial language and that in the forms with -er the plural concept emerges more sharply. Bande is = 'bond' in a strict and in an extended meaning ('bond of friendship') and is never connected with number; otherwise, the plural Bänder is used. Luther only has Bande. Lande is more ceremonial than Länder and is also not easily connected with number [my translation, LG].
} 
Table 1

The German nouns with plural variants $-e r /-e$.

\begin{tabular}{|c|c|c|c|}
\hline 1. & Band (neut.) 'tape, bond' & Bänder 'tapes, ties' & Bande 'bonds' \\
\hline 2. & Ding 'thing' & Dinger & Dinge \\
\hline 3. & Gesicht 'face, vision' & Gesichter 'faces' & Gesichte 'visions' \\
\hline 4. & Horn 'horn' & Hörner & Horne (substance) \\
\hline 5. & Land 'land' & Länder & Lande \\
\hline 6. & Mann 'man' & Männer & Mannen \\
\hline 7. & Mark (fem.) 'mark' & Märker & Mark \\
\hline 8. & Ort (masc.) 'place, point' & Örter 'points' & Orte 'places' \\
\hline 9. & Stück 'piece' & Stücker & Stücke \\
\hline 10. & Tuch 'cloth, drapery' & Tücher 'clothes' & Tuche 'draperies' \\
\hline 11. & Wort 'word' & Wörter & Worte \\
\hline 12. & Balg 'brat' & Bälger & Bälge \\
\hline 13. & Bösewicht 'villain' & Bösewichter & Bösewichte \\
\hline 14. & Brot 'bread' & Bröter & Brote \\
\hline 15. & Bruch 'marsh' & Brücher & Brüche \\
\hline 16. & Denkmal 'monument' & Denkmäler & Denkmale \\
\hline 17. & Dorn 'thorn' & Dörner & Dornen \\
\hline 18. & Geschmack'taste' & Geschmäcker & Geschmäcke \\
\hline 19. & Klotz 'block of wood' & Klötzer & Klötze \\
\hline 20. & Licht 'light' & Lichter & Lichte 'candles' \\
\hline 21. & Mal 'time, mark, monument' & Mäler 'monuments' & Male 'times, marks' \\
\hline 22. & Mund 'mouth' & Münder & Munde/Münde \\
\hline 23. & Rest 'remnant' & Rester & Reste \\
\hline 24. & Ross 'horse, steed' & Rösser 'horses' & Rosse 'steeds' \\
\hline 25. & Scheit 'piece of wood' & Scheiter & Scheite \\
\hline 26. & Scheusal 'monster' & Scheusäler & Scheusale \\
\hline 27. & Trumm 'whopper' & Trümmer & Trumme \\
\hline
\end{tabular}

Table 2

The development of the suffix -ir- in OHG.

\begin{tabular}{llll}
\hline & & early OHG & late OHG \\
\hline \multirow{2}{*}{$\mathrm{Sg}$} & $\mathrm{N} / \mathrm{A}$ & lamb 'lamb' lamb \\
& $\mathrm{G}$ & lemb-ir-es & lamb-es \\
& $\mathrm{D}$ & lemb-ir-e & lamb-e \\
$\mathrm{P} 1$ & $\mathrm{~N} / \mathrm{A}$ & lemb-ir & lemb-ir \\
& $\mathrm{G}$ & lemb-ir-o & lemb-ir-o \\
& $\mathrm{D}$ & lemb-ir-um & lemb-ir-um \\
& &
\end{tabular}

In particular, the pairs from 1 to 11 in Table 1 are to a large extent covered by Paul's generalization, as confirmed by their (in)compatibility with numerals (e.g. drei Männer/*Mannen 'three men', zwei Länder/*Lande 'two regions', fünf Wörter/*Worte 'five words', but ein paar Wörter/Worte 'a few words', etc.). Note that the individualizing value of the er-plural can also give rise to more specific semantic nuances such as pejorative or derogatory values (e.g. Dinge 'things' vs. Dinger 'junks', Mark 'marks' vs. Märker 'pennies'). Such nuances can typically be found in more colloquial, jocular registers as in the case of Stücker (cf. the expression Stücker zehn 'about ten') vs. Stücke. On the other hand, the more abstract, holistic value of the e-plural may give rise to more abstract semantic nuances, as in Bänder 'tapes' vs. Bande 'bonds', Gesichter 'faces' vs. Gesichte 'visions', Tücher 'clothes' vs. Tuche 'draperies', etc. More generally, the e-plural is often restricted to written registers as in the case of Lichte, Munde, Rosse, etc., in line with Paul's observation quoted above. In addition, the er- and the $e$-plural are also subject to diatopic variation, insofar as the former is more widespread in southern varieties of German, especially in Bavaria and Austria (e.g. Bröter, Dörner, Klötzer, Trümmer, etc.). ${ }^{4}$

One particularly interesting aspect of the er-plural is its origin in an earlier stem form -ir-. This was refunctionalized in late Old High German $(\mathrm{OHG})$ as a plural marker and accordingly radically eliminated from the singular:

The result of this refunctionalization, which can be treated as a case of exaptation - i.e. the reuse of older morphological material in a new function (cf. Gaeta, 2016) - was a new inflectional class, the so-called Hühnerhofklasse 'animal farm class'. This class was originally limited to a dozen neuters referring to small animals, and then expanded to other nouns relating to farming such as Feld 'field', Korn 'corn', etc.; subsequently, it enlarged considerably up to a hundred nouns occurring in the lexicon of Present-Day German (= PDG). Although the class cannot be said to be productive, it is fairly stable and surreptitiously enriched

\footnotetext{
${ }^{4}$ It has to be added that in Southern varieties the expansion of the $e r$-plural is also favored by the widespread phonological process of schwa loss in final position, rendering the $e$-plural opaque (cf. Wegener, 2002).
} 
by one productive derivational suffix, namely -tum: cf. Alter 'age' $\rightarrow$ Altertum/Altertümer 'antiquity/antiquities'; eigen 'own, proper' $\rightarrow$ Eigentum/Eugentümer 'property/properties', etc.

Now, we might ask how the plural doublets developed secondary meanings preserving the old suffix as in Gesichte 'visions', Mannen 'vassals', Tuche 'draperies', etc., while the new suffix -er, expanding as a result of the exaptation process mentioned above, assumed the 'granular' plural meaning in compliance with Kuryłowicz' fourth law. This law follows a general teleological principle whereby the redundancy - or in our case, the older morphological variant - is preserved only if it develops a certain function; otherwise it disappears, as happened in the English pairs cows/kine, houses/housen, etc. This principle maintains that language systems tend towards a maximal functionalization of form-meaning pairs, resulting in a more efficient attribution of functional load.

In this section, I have discussed the case of morphological differentiation involving plural doublets, presenting solid evidence of the later origin and expansion of the exapted marker -er - which developed at the expense of the other plural markers, which, in turn, were relegated to a minor role. In the next section, I will discuss a more complex case which lends support to a Principle of Maximal Differentiation, according to which a form develops new formal variants as a consequence of the change of its function.

Before turning to that issue, let us conclude the discussion of the German plural doublets by considering whether the examples in Table 1 constitute a true case of category formation, as suggested above. Insofar as the new marker -er provides a granular meaning that flanks the collective or holistic meaning supplied by the older markers (-e or -en), we might indeed envision a scenario in which new and old plurals coexisted for a while, favoring the stabilization of the plural doublets listed in Table 1 . In individual cases, when the semantic distance between the members of the doublet became too great, the meaning differentiation might also have led to lexical differentiation, as for Männer 'men'/Mannen 'vassals' (similar to brothers/brethren). However, given the rather restricted number of doublets as well as their heterogeneous character, we cannot really speak of a completed process of category formation. This is probably due to the fact that the plural doublets were not salient enough for the speakers and their role in the German inflectional system has remained quite marginal.

\section{Morphological differentiation and grammaticalization}

\subsection{Morphological differentiation as a consequence of grammaticalization}

The issue of morphological differentiation becomes more interesting when it is not confined to the expansion of a specific inflectional class resulting from exaptive change, but involves the more general process of grammaticalization giving rise to a genuinely new category; in Gaeta (2016), this process has been called an adaptive change. In contrast to exaptive change, adaptive change encompasses constructions undergoing general processes of semantic bleaching connected with their routinization and generalization, following their social success within a speaker's community. Moreover, these grammaticalized constructions increase the complexity of the grammar as they encode more abstract and general meaning in terms of more concrete and specific expressions (e.g. time in terms of space, definiteness in terms of spatial proximity, to name a few). Finally, the new constructions encode a new grammatical distinction or renovate an already present one. In short, adaptive changes meet the three requirements of social value, complexity, and distinctiveness (cf. Lindblom, 1998). In addition, they are essentially directional in that they proceed from a concrete to an abstract meaning and in that they originate from widely attested processes of variation and meaning extension (cf. Haspelmath, 1999).

While in the examples discussed in Section 2, the morphological differentiation resulting from exaptive change did not lead to successful category formation, the present section discusses a case of genuine categorial shift accompanied by category formation; it involves deictic expressions and is brought about by a more general process of grammaticalization (see Diessel, 1999, among others). It is important to stress that this process of grammaticalization can be argued to have preceded the morphological differentiation, such that it might in fact be suggested that there is a cause-effect relation between them whereby the differentiation is due to grammaticalization. In other words, the new function is hypothesized to have triggered a change in the form.

This idea is not new in the domain of grammaticalization studies and has generally been discussed in connection with the decategorialization (cf. Hopper and Traugott, 2003, pp. 106-109; Gaeta, 2014). For instance, Di Meola (2000, p. 144; 2002, p. 104) has formulated the following Principle of Maximal Differentiation (= PMD) with regard to the original structure: ${ }^{5}$

\section{Principle of Maximal Differentiation}

In the course of grammaticalization, a progressive differentiation of the form involved takes place with regard to its original morphophonological and semantic structure as well as to its original syntactic context.

\footnotetext{
${ }^{5}$ Cf. Di Meola (2003, p. 104): "Prinzip der Maximalen Differenzierung gegenüber der Ursprungsstruktur: Im Zuge der Grammatikalisierung findet eine progressive Abkehr von der ursprünglichen morphophonologischen Struktur und semantischen Struktur sowie von der ursprünglichen syntaktischen Umgebung der betreffenden Form statt".
} 
Accordingly, grammaticalization leads to the differentiation - potentially at any linguistic level - of a particular morpheme with respect to its source morpheme. This brings in a teleological perspective in that the formal innovation is meant to make the morpheme easier to identify in the new function. In more concrete terms, the speakers are assumed to infer a new profile of the grammaticalized morpheme from the different contexts in which it is being used and to act so as to increase its difference with regard to the source morpheme.

The strongly teleological orientation of Di Meola's PMD is in conflict with the Principle of Prototypization (= PP), which is generally taken to underlie our cognitive apparatus insofar in that it aims at the optimization of a linguistic item's function, resulting in its high saliency (cf. Seiler, 1989, p. 2). Di Meola sees categorial shifts as driven by the interaction of the PP and of the PMD in that the former takes priority over the latter; only if the PP fails to apply, then the PMD can take effect. Di Meola's examples have been taken from the domain of German adpositions and involve especially those adpositions that can be argued to have undergone grammaticalization.

Prototypical features of German adpositions are pre-posing and dative selection. Accordingly, all changes leading to the acquisition of these features are deemed to be in accordance with the PP. In particular, the tendency towards pre-posing is clearly in line with the PP insofar as postpositions are rare and recessive, as shown by the examples in (2a-b) and (2c-d). In fact, no shift from pre-position to post-position can be observed in German adpositions. The status of the other feature is however far less clear. Since Di Meola assumes dative selection to be prototypical, only the change in (2f) meets the PP because the older genitive selection observed in $(2 \mathrm{c})$ is replaced by the allegedly prototypical dative. In contrast, the change observed in (2e), in which the genitive replaces the older dative occurring in (2a-b) runs counter to prototypization; it is therefore better accounted for in terms of the PMD, for which it actually provides substantial evidence.

(2) a.

b.

c.

d.

e.

f. postposition>preposition

Ein wenig weiter, $\left[[\text { den Gleisen }]_{\mathrm{DAT}} \text { entlang }\right]_{\mathrm{POSTP}}, z u$ Fuß zu erreichen, kommt der unterirdische Karstfluß Timavo ans Licht.

'A little further, along the rails, to be reached on foot, the subterranean karst river Timavo emerges.'

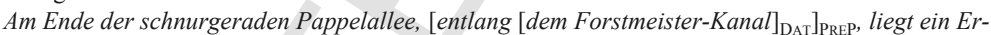
holungszentrum mit Restaurant.

'At the end of the dead straight Pappel alley, along the Forstmeister channel, there is a recreation center with a restaurant.'

$[$ W]as hier als Delikatesse gilt, mußte in Westberlin von den Fischern [[des hochbelasteten Wassers $]_{\mathrm{GEN}}$ wegen $]_{\text {POSTP }}$ noch immer als Sondermüll entsorgt werden.

'What counts here as a delicacy had to be yet disposed of as special waste by the fishermen in West Berlin because of the highly contaminated water.'

Allein in den letzten zwölf Monaten nahm die öffentliche Schuld um 190 Milliarden Mark zu, zum größten Teil $\left[\text { wegen }[\text { der Zinszahlungen }]_{\mathrm{GEN} / \mathrm{DAT}}\right]_{\mathrm{PREP}}$ für die Gesamtschuld.

'In the last twelve months alone the public debt increased by 190 billion mark, to a large extent because of the interest payments on the total debt.'

dative $>$ genitive

$\left[\text { Entlang }[\text { des Malecon }]_{\mathrm{GEN}}\right]_{\mathrm{PREP}}$ befinden sich noch einige kleine Badebuchten, die jedoch meist nicht sehr sauber sind.

'Along the Malecon there still are some small swimming bays which, however, are mostly not very clean.'

genitive $>$ dative

$\left[\text { Wegen }[\text { dem Oberleutnant }]_{\mathrm{DAT}}\right]_{\mathrm{PREP}}$, den ich hinter mir spürte, vermied ich es, in Laufschritt zu fallen.

'Because of the first lieutenant whom I sensed was behind me I avoided to fall at the double.' (examples from Di Meola, 2000, 2002)

One problem with Di Meola's account comes from the fact that it is often not easy to isolate one single prototype driving a particular prototypization. This is true especially in the domain of adpositions, which usually arise from various source constructions and accordingly may display different and mixed features. In this case, the trigger driving the change observed in (2e) might have been the pattern of (originally denominal) pre-positions which normally select the genitive, such as anhand 'by means of', anstelle 'instead of', aufgrund 'on the basis of', infolge 'in consequence of', etc. (cf. Zifonun et al., 1997, p. 2075), which might qualify as an alternative prototype with regard to that assumed by Di Meola, also inducing the effect of the PP. In addition, we should not forget the effect of case syncretism occurring especially between the genitive and the dative of feminine nouns; these nouns form the bulk of abstract nouns thanks to the high productivity of suffixes like -heit, -schaft, -ung, etc., as 
shown for instance by example (2d), where both analyses are available. ${ }^{6}$ In sum, the case shift dative $>$ genitive observed in (2e) cannot really be used as evidence in support of the PMD; instead, it has to be explained away as due to the influence of an alternative prototype robustly attested by several grammaticalized prepositions like anhand, aufgrund, mithilfe, etc. Thus, the change in (2e) arguably does not provide evidence in support of the PMD, because it in fact reflects the effect of the PP, provided that more than one prototype can arguably be established.

\subsection{Categorial shifts and innovating grammaticalization}

In the light of the previous discussion, the evidence in support of the PMD has to be sought in cases where the effects of the PP are clearly to be excluded: these are virtually only instances of 'innovating grammaticalization' (see Lehmann, 2015, p. 22) resulting in the creation of a new grammatical category which obviously cannot be influenced by any preexisting prototype. In contrast, the cases seen in (2) above can be covered by the label of 'renovating grammaticalization', because both the position and the case shift affect new members of the preexisting category of adpositions, namely wegen $(<$ Weg 'way') and entlang $(<$ in 'in' + lang 'long'). As discussed above, entlang can be subject to the different prototypes which are already active within the preexisting category.

One example of a categorial shift featuring an innovating grammaticalization involves the German definite article der. This definite article had as source morpheme a demonstrative pronoun which underwent a parallel grammaticalization path as a relative pronoun (see Szczepaniak, 2009, pp. 73-78 for a survey). For our purposes, the important point is that since the Middle High German (= MHG) period, a process of morphological differentiation involving the article has been under way, which has not yet finished today. This concerns mainly the oblique cases of the demonstrative and of the relative pronoun, which are boldfaced in Table 3:

Clearly, in terms of generality of usage - and therefore frequency - the article has to be considered unmarked with regard to demonstrative and relative pronouns (though these are the source items). Thus, it does not come as a surprise that these pronouns underwent formal changes in accordance with the expectations of Kuryłowicz' fourth law of analogy. Note that while for the relative pronoun no preexisting prototype can be established, one might tentatively assign this role to the more frequent demonstrative pronoun dieser 'this', which in its turn results from the reinforcement of the old demonstrative der. However, except perhaps for its disyllabic skeleton, dieser does not seem to have played any role in the inflectional development of der, as shown by the demonstrative's forms of the (masculine/neuter) genitive singular dieses and genitive plural dieser, which cannot be connected with dessen or denen. Thus, the differentiation observed in Table 3 does not follow a similarity-increasing principle like the PP. Rather, the changes enhance dissimilarity as required by the PMD.

On the other hand, despite the absence of an immediate prototype, other categories might have played a role in the process of differentiation. In other words, the question arises as to the source of the linguistic material recruited to bring about the dissimilarity. In this regard, two hypotheses have been proposed. According to Lühr (1991), the morphological differentiation followed an analogical pattern modeled after the 3rd person personal pronoun. The analogical extension started from the form of the masculine accusative singular den and followed the four-term proportion in: den=inen: $\mathrm{X}(=$ denen). Thus, the dative plural form denenalready attested in the 14th century - is allegedly modeled after the corresponding dative plural form inen of the 3rd person personal pronoun paralleling the masculine accusative singular forms in and den. Support for this view comes from the coexistence of the forms in and inen, respectively for the masculine accusative singular and for the dative plural of the 3rd person personal pronoun observed in Alemannic varieties since the 12th century. This analogical change was subsequently extended to the feminine singular forms inen and denen paralleling the genitive plural forms iren and deren, according to the following proportional analogy: inen: denen=iren: $\mathrm{X}(=$ deren $)$. In addition, the extension was helped by the common occurrence in the prenominal position: Sie sehen die eltern und iren/deren $(<d e r)$ sun 'They see the parents and their (lit. of them/of these) son'. Subsequently, deren served as model for the new shape of the masculine genitive singular dessen attested in the 15th century. The next step is the extension of the form deren to the feminine dative singular which is identical to the genitive. Notice that this extended form was not established in the modern variety. In the 16th century, the feminine genitive singular and the genitive plural derer were formed again on the basis of the personal pronoun: inen: denen=irer: $\mathrm{X}(=$ derer $)$; the form derer was subsequently extended to the dative singular, but here, derer fell out of use again.

The ingredients of this complex account are (i) the tendency towards formal differentiation due to the PMD; (ii) the influence of the formal model of the personal pronoun from which the elements -en and -er are carried over, especially favored by the prenominal overlapping contexts; (iii) the analogical extension based on a four-term proportion; (iv) the assessement of -en and $-e r$, not as morphemes exhibiting a semantic value and subsequently exapted in a new function, but simply as part of the shape of the personal pronoun extended in various and disparate contexts like dessen, denen, etc.

An alternative explanation is proposed by Bærentzen $(1995,2011)$, who points to the influence of another possible attractor, namely adjectival inflection. Bærentzen's account addresses Lühr's inability to explain the different distribution observed in

\footnotetext{
${ }^{6}$ In this regard, it would be interesting to know to what extent feminine nouns - and in particular abstracts in common expressions like anhand der Häufigkeit 'on the basis of the frequency', aufgrund der Verwandtschaft 'on the basis of the affinity', mithilfe der Stiftung 'with the help of the foundation', etc. - occur in combination with these prepositions in order to get a precise idea of the role of case syncretism in this connection (cf. Gaeta, 2003).
} 
Table 3

The article, the demonstrative, and the relative pronoun in MHG and in PDG.

\begin{tabular}{|c|c|c|c|c|c|c|c|c|c|c|}
\hline & & \multicolumn{3}{|l|}{ MHG } & \multicolumn{6}{|c|}{ PDG } \\
\hline & & \multicolumn{3}{|c|}{ Art/Dem/Rel } & \multicolumn{3}{|l|}{ Art } & \multicolumn{3}{|l|}{ Dem/Rel } \\
\hline & & M & $\mathrm{N}$ & $\mathrm{F}$ & M & $\mathrm{N}$ & $\mathrm{F}$ & M & $\mathrm{N}$ & $\mathrm{F}$ \\
\hline \multirow[t]{4}{*}{$\mathrm{Sg}$} & $\mathrm{N}$ & der & $d a z$ & diu & der & das & die & der & das & die \\
\hline & $\mathrm{G}$ & des & & $\operatorname{der}(e)$ & des & & der & dessen & & deren/derer \\
\hline & $\mathrm{D}$ & $\operatorname{dem}(e)$ & & $\operatorname{der}(e)$ & dem & & der & dem & & der \\
\hline & A & den & $d a z$ & die & den & das & die & den & das & die \\
\hline \multirow[t]{4}{*}{$\mathrm{Pl}$} & $\mathrm{N}$ & die & diu & die & die & & & die & & \\
\hline & G & $\operatorname{der}(e)$ & & & der & & & deren/derer & & \\
\hline & $\mathrm{D}$ & den & & & den & & & denen & & \\
\hline & $\mathrm{A}$ & die & diu & die & die & & & die & & \\
\hline
\end{tabular}

PDG between the forms deren/derer, which are simply listed as allomorphs in Table 3. In truth, the distribution of these allomorphs is context-sensitive, as no difference between the demonstrative and the relative pronoun can be found:

(3)

C 1

C2:

C4:

C5:
_ $]_{\mathrm{NP}}$ : dort begegnete man Dichtern $\mathrm{i}_{\mathrm{i}},\left[\right.$ deren $_{\mathrm{i}}$ Werke $_{\mathrm{NP}}$ man kannte.

0 'poets could be met there whose works were known'

_... Q $]_{\mathrm{QP}}$ : Was für einen Retriever ${ }_{\mathrm{i}}$ meinst du? Es gibt deren $\mathrm{i}_{\mathrm{i}}$ ja nunmal $[6 \text { verschiedene }]_{\mathrm{Q}}$. 0 'What kind of retriever do you mean? There are 6 different types thereof after all.'

$\left.\ldots{ }_{-} \ldots\right]_{\mathrm{S}}$ : Die meisten Güter $r_{\mathrm{i}},\left[\text { deren }_{\mathrm{i}} \text { der Mensch bedarf }\right]_{\mathrm{S}}$, sind vermeidbar.

0 'Most goods which man needs are not essential.'

Prep _ $]_{\text {Prep }}$ : Auf der Rasenfläche ${ }_{\mathrm{i}}$, [inmitten derer $\left.]_{\mathrm{i}}\right]_{\text {PreP }}$ die Kirche lag, standen auch einige Pinien.

0 `On the lawn in the middle of which where the church was located there were

also some pines.'

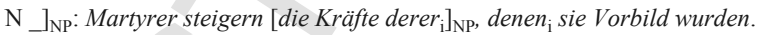
0 'Martyrs enhance the force of those for whom they became an example.'

In short, deren is preferred in those contexts in which it precedes its syntactic head - as prenominal modifier (3-C1), as modifier of quantifying expressions (3-C2), and as a verbal argument (3-C3) - while derer prefers to follow its syntactic head - as complement of a preposition (3-C4) or as postnominal modifier (3-C5). This is shown by Fig. 1, based on the data by Bærentzen (1995), who collected about 2750 tokens coming from PDG texts:

To account for this distribution, Bærentzen suggested that the form deren was modeled after the adjectival inflection which obligatorily precedes the nominal head and mostly displays a nasal suffix, while the form derer corresponds to the genitive case-marking of most attributes following a nominal head. In other words, the morphosyntactic context imposes a morphological differentiation which aims at making the demonstrative/relative pronoun more similar to the prototypical attributes

either

preceding

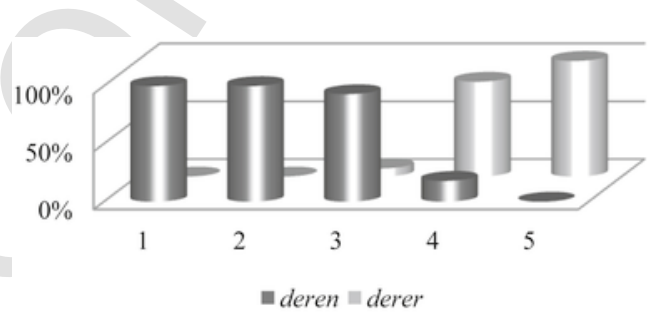

Fig. 1. The distribution of deren/derer over context C1-C5. 
or following the nominal head $(4 a-b)$ :

(4) a. der schönen Frau 'of the beautiful woman' deren Gesicht 'her / whose face' der alten Häuser 'of the old houses' deren Dach 'their / whose roof' b. der Hauch frisch $\underline{\underline{e}}$ Luft 'the breath of fresh air' der Hauch derer 'the breath of this' inmitten der Felder 'amidst the fields' inmitten derer 'amidst these / which'

c. die Verarbeitung tropisch $\underline{\text { en Holzes die Verarbeitung dess } \underline{\text { en }}}$

'the manufacturing of tropical wood' 'the manufacturing of this'

$\begin{array}{ll}\begin{array}{ll}\text { aufgrund tropischen Holzes } \\ \text { 'on the basis of tropical wood' }\end{array} & \begin{array}{l}\text { aufgrund dessen } \\ \text { 'on the basis of this' }\end{array} \\ \text { d. des hohen Grades } & \text { dess } \underline{\underline{e n}} \text { Grad } \\ \text { 'of the high degree' } & \text { 'its / whose degree' }\end{array}$

Notice that this explanation also holds for the form dessen, which closely corresponds to the prototypical marking of an adjective following or preceding a nominal head, as in $(4 c-d)$. With respect to Lühr's account, this explanation shares (i) the tendency towards formal differentiation due to the PMD, but assumes (ii) the influence of the formal model of adjectival inflection from which the elements -en and -er - respectively in prenominal and postnominal contexts - are transferred. In contrast to Lühr's, however, Bærentzen's explanation (iii) accounts for the differentiation on the basis of a syntagmatic extension which cannot be reduced to a four-term proportion, and (iv) considers -en and -er as true inflectional endings whose new, exapted function is to fill the inflectional slots of the demonstrative/relative pronoun corresponding to certain morphosyntactic environments. However, the form dessen presents a problem for this analysis because the pattern in (4c), in which the nominal head is followed by a genitival complement without any determinant, is quite rare and in fact restricted to a small set of nouns. On the other hand, although the form dessen also matches a prenominal model as shown by (4d), it does not show the clear contrast between the prenominal deren and the postnominal derer which is at the heart of Bærentzen's hypothesis.

It has to be stressed that the complex sets of analogical extensions, as differently reconstructed by Lühr and Bærentzen, seem to share the same purpose, namely to differentiate the article from the demonstrative/relative pronoun. The changes primarily obey the PMD in that linguistic material is adopted from other categories, namely personal pronoun forms and inflectional forms of the adjective. These, however, cannot be considered true prototypes capable of exerting an attractive force. They merely serve as formal models for the morphological differentiation on the basis of partially overlapping syntactic contexts favoring the analogical extensions. It must also be added that in contrast with the case of prepositions seen above, the differentiation does not concern the innovating category of the article, but the older one which served as its source. As has been hinted at above, this might be due to the higher frequency of the innovating category, the article, while the demonstrative - and a fortiori the relative - pronoun is far less frequent (also because of the competition of other morphemes like dieser). In other words, the state of affairs sketched here is reminiscent of the case of brothers/brethren seen in Section 2.1, where the new form is also the unmarked one. Thus, the differentiation, i.e. the ongoing dynamics, is not necessarily related to the newly emerging category which directly undergoes the categorial shift but concerns the whole system. In this light, we might attempt to modify Di Meola's PDM, which only focuses on the morphemes undergoing the categorial shift, and suggest the following revised principle:

\section{Principle of Maximal Differentiation (revised version)}

In the course of a language change having an impact on the categorial status of particular linguistic units, a progressive differentiation of the forms involved takes place with regard to their original morphophonological and semantic structure as well as their original syntactic context.

In the next section, I will briefly try to explain how the differentiation ultimately resulting from the PMD came about in the case of the different forms of the German demonstrative/relative pronoun. 


\subsection{The context-sensitivity of morphological differentiation}

Given the clear distribution of deren and derer in PDG, we might expect the process of differentiation to follow a particular path mirroring the context-sensitivity of the respective forms. To test this hypothesis, I carried out a small study on the basis of the Bonner Frühneuhochdeutschkorpus (= BoFnhdC) covering the Early New High German (= ENHG) period from the middle of the 14 th century until the end of the 17 th century and containing about 480,000 tokens. Note that besides the modern forms derer and deren other variants occur, namely dero and dere; they are, however, omitted in Table 4, which adopts Bærentzen's contexts seen in (3) above:

Although deren is overall more frequent than derer, their behavior turns out to be curiously divergent. While deren divides its labor across all contexts with a clear preference for $\mathrm{C} 2$ and $\mathrm{C} 1$, derer, in spite of its reduced distribution, appears to be profiled in a better way than deren with regard to $\mathrm{C} 5$, and partially so with regard to $\mathrm{C} 2$ and $\mathrm{C} 3$. This is because in $\mathrm{C} 5$ derer is a better index of its usage context than deren, whose interpretation as an index of $\mathrm{C} 5$ is less probable compared to its other possible interpretations referring to the other usage contexts. In this sense, the distribution of derer performs better than that of deren independently of their overall frequency, insofar as the form derer gives a clearer clue to its usage context than deren. The characterization of derer and deren as indexes of their respective usage contexts is presented in Fig. 2.

In other words, while using deren does not allow the listener to gauge in a straightforward way its usage context except for $\mathrm{C} 1$, using derer is more conducive than deren to an interpretation in terms of $\mathrm{C} 5$, and to a less clear extent in terms of $\mathrm{C} 3$ - where the anaphoric pattern seen in (3) largely prevails (see example 5a) - and in terms of C2 - where also left-headed cataphoric examples $\operatorname{occur}(5 b)$ :

(5)

b.

\author{
Jch bin dein Knecht vnd $S_{u}^{e}$ dentreger worden/vnd habe $\left[\text { deine } S_{u}^{e} \text { nde vnd vnreinigkeit }\right]_{\mathrm{i}}$ von dir

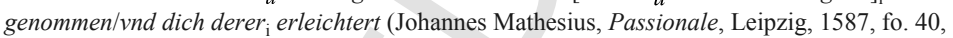 \\ 26-29) \\ 'I became your slave and sinner and I took over your sin and impurity from you and I relieved you \\ from them.' \\ Es $m_{o}^{e}$ gen wol $[\text { viele }]_{\mathrm{Q}}$ derer $_{\mathrm{i}}$ seyn/die ${ }_{\mathrm{i}}$ gern regiren $m_{O}^{e}$ chten (Sigmund von Birken, Spiegel, Nürn- \\ berg 1668 , p. 77, col. B, 28-29) \\ 'There might well be many of those who would like to govern.'
}

With regard to $\mathrm{C} 4$, the evidence is too scanty to allow for any conclusion. Such a characterization of derer compared to deren as indexes of their usage context is completely overlooked if only the overall frequency of the variants relating to the single contexts is considered, as in Fig. 3, which presents the proportions of deren and derer for each of the five contexts. Note that in Fig. 2 , the percentages for deren and derer sum up to $100 \%$ across categories (as in Table 4), while in Fig. 3, the percentages for each context category sum up to $100 \%$. This entails that in Fig. 3, deren clearly wins out everywhere because of its higher frequency.

Table 4

The distribution of derer and deren in the respective contexts in the BoFnhdC

\begin{tabular}{|c|c|c|c|c|c|c|c|c|c|c|c|c|}
\hline \multirow[b]{3}{*}{$\mathrm{C} 1$} & \multicolumn{4}{|c|}{ Relative } & \multicolumn{4}{|c|}{ Demonstrative } & \multicolumn{4}{|c|}{ Total } \\
\hline & \multicolumn{2}{|c|}{ deren } & \multicolumn{2}{|c|}{ derer } & \multicolumn{2}{|c|}{ deren } & \multicolumn{2}{|c|}{ derer } & \multicolumn{2}{|c|}{ deren } & \multicolumn{2}{|c|}{ derer } \\
\hline & 28 & $31 \%$ & - & - & 20 & $30 \%$ & - & - & 48 & $31 \%$ & - & - \\
\hline $\mathrm{C} 2$ & 37 & $41 \%$ & 4 & $100 \%$ & 21 & $32 \%$ & 5 & $31 \%$ & 58 & $37 \%$ & 9 & $45 \%$ \\
\hline $\mathrm{C} 3$ & 18 & $20 \%$ & - & - & 7 & $11 \%$ & 4 & $25 \%$ & 25 & $16 \%$ & 4 & $20 \%$ \\
\hline $\mathrm{C} 4$ & 1 & $1 \%$ & - & - & 2 & $3 \%$ & - & - & 3 & $2 \%$ & - & - \\
\hline $\mathrm{C} 5$ & - & - & - & 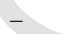 & 12 & $18 \%$ & 4 & $25 \%$ & 12 & $8 \%$ & 4 & $20 \%$ \\
\hline Others & 7 & $8 \%$ & - & - & 4 & $6 \%$ & 3 & $19 \%$ & 11 & $7 \%$ & 3 & $15 \%$ \\
\hline Tot & 91 & $100 \%$ & 4 & $100 \%$ & 66 & $100 \%$ & 16 & $100 \%$ & 157 & $100 \%$ & 20 & $100 \%$ \\
\hline
\end{tabular}

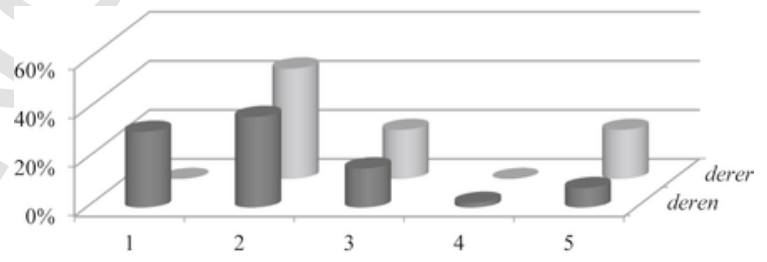

Fig. 2. The comparison of deren/derer with regard to the usage contexts. 


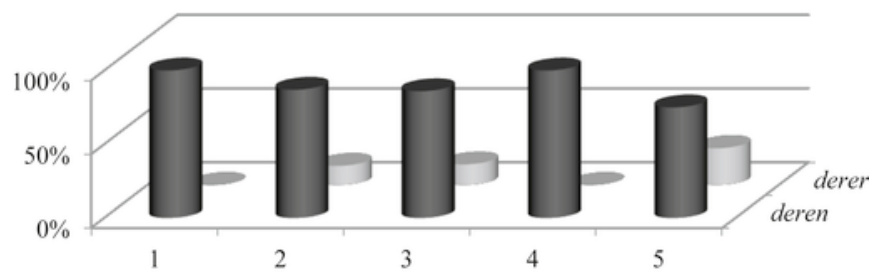

Fig. 3. Overall distribution of deren/derer in the different contexts.

Clearly, derer's small numbers only allow us to detect traces of its salience with regard to left-headed constructions as they are robustly found in the PDG examples seen in (3-C4) and (3-C5); yet all conditions are in place for its further expansion into the actual state of affairs. Thus, the development is not as unexpected as it might appear on the basis of Fig. 3 where deren is the only dominant variant. A formal differentiation was already present in ENHG; it was certainly less distinct because of the higher frequency of deren, but sufficiently well-profiled to allow speakers to draw the inferences which led to the present state of affairs, where deren is found in the right-headed $\mathrm{C} 1$ and derer in the left-headed $\mathrm{C} 5$.

\section{Conclusion}

To sum up, differentiation is undoubtedly a fundamental issue emanating from the tectonics of the language systems which evolve over the course of time through various processes of language change. In particular, I have discussed two different instances of morphological differentiation in the history of German. In the first instance, which can be qualified as a case of exaptive change, the refunctionalization of the er-marker gave rise to plural doublets; these could be partially interpreted as semantically distinct insofar as the exapted marker assumed the granular meaning typical of the plural while the older markers were restricted to a holistic value. This state of affairs is fairly well captured by Kuryłowicz' fourth law of analogy. Importantly, though, this exaptive change did not give rise to a new category within the inflectional system such as 'granular vs. holistic plural', probably because the number of plural doublets involved in the morphological variation was too small and heterogeneous.

In the discussion of the second case of morphological differentiation, in which an adaptive change resulted in the differentiation of articles from demonstrative/relative pronouns, an active principle of differentiation has been put forward, the PDM, which is meant to account for the dynamics of linguistic units undergoing categorial shifts. Some caution needs to be exercised with this principle, though, in that it appears to be legitimate only in the absence of any evident effect of prototypization with regard to the target category. In the discussion of the morphological differentiation in German adpositions (see Di Meola, 2000, 2002), such prototypization effect turned out to be at odds with the PDM. But even in a clear-cut case supporting the PDM as a principle serving the general purpose of enhancing the autonomy of grammatical categories, such as the German deictic expressions, the differentiation concerned the morphemes representing the source rather than the result of the grammaticalization process. The development of the German demonstrative/relative pronouns shows that the association of specific forms with morphosyntactic contexts provides detailed information guiding the change (or, development) of the inflectional paradigm towards its formal differentiation from the article. This development is goal-oriented in nature insofar as it enhances the efficiency of the functional load associated with the retrieval of the category 'pronoun' in contrast with the article. To do this, speakers exploit the properties occurring in the speech signal - independently of how they come into being (e.g. via partial overlapping with other categories such as the personal pronoun or the adjectival modifier) - thus optimizing, on the basis of their inferences, the detectability of categorial membership. In this way, the PMD contributes to category formation in the context of linguistic units undergoing categorial shifts. Moreover, the differentiation obeys markedness principles insofar as the demonstrative/relative pronouns are less frequent than the article, richer - or less bleached - in terms of semantic or syntactic features, and accordingly more restricted in their distribution. The PDM thus helps establish an asymmetric coding between the less marked article and the more marked pronouns (cf. Haspelmath, 2008; Gaeta, 2017).

As a final remark, it is worth pointing out that categorial shifts are usually held to give rise to feature alignment in terms of decategorization with regard to the source category, followed by a recategorization in the target category (cf. Malchukov, 2004; Gaeta, 2014). This paper has shown how categorial shifts of different nature bring about the reorganization of emerging features like the plural -er, the genitive case of the prepositions or the several variants of the demonstrative/relative pronoun, which simply turn out to be misaligned with respect to their origin. Thus, prototypization and differentiation represent two different faces of the same coin, namely categorization.

\section{Uncited reference}

BoFnhdC. 


\section{References}

Bærentzen, P., 1995. Zum Gebrauch der Pronominalformen deren und derer im heutigen Deutsch. Beitr. Gesch. Dtsch. Sprache Lit. 117, $199-217$.

Bærentzen, P., 2011. Einige neue Regularitäten im Gebrauch der Pronominalformen deren und derer. In: In: Konopka, M., Kubczak, J., Mair, Ch, Sticha, F., Waßner, U.H. (Eds.), Grammatik \& Korpora 2009: Dritte Internationale Konferenz Mannheim 22.-24.09.2009, vol. 1, Narr Francke Attempto Verlag, Tübingen, pp. 199-211.

BoFnhdC = Bonner Frühneuhochdeutschkorpus, https://korpora.zim.uni-duisburg-essen.de/Fnhd/.

Di Meola, C., 2000. Die Grammatikalisierung deutscher Präpositionen. Stauffenburg, Tübingen.

Di Meola, C., 2002. Präpositionale Rektionsalternation unter dem Gesichtspunkt der Grammatikalisierung. In: Cuyckens, H., Radden, G. (Eds.), Perspectives on Prepositions. Niemeyer, Tübingen, pp. 101-129.

Diessel, H., 1999. Demonstratives: Form, Function, and Grammaticalization. John Benjamins, Amsterdam, Philadelphia.

Gaeta, L., 2003. Grammar and grammaticalization: the case of German. Riv. Ling. 15 (1), 173-190.

Gaeta, L., 2008. Die deutsche Pluralbildung zwischen deskriptiver Angemessenheit und Sprachtheorie. Z. Ger. Linguist. 36 (1), $74-108$.

Gaeta, L., 2014. On decategorization and its relevance in German. In: Simone, R., Masini, F. (Eds.), Word Classes: Nature, Typology and Representations. John Benjamins, Amsterdam, Philadelphia, pp. 227-241.

Gaeta, L., 2016. Co-opting exaptation in a theory of language change. In: Norde, M., Van de Velde, F. (Eds.), Exaptation in Language Change. John Benjamins, Amsterdam, Philadelphia, pp. 57-92.

Gaeta, L., 2017. Diachronic sources of asymmetric coding. Paper delivered at the workshop on Linguistic coding asymmetries, usage frequency and informativeness. In: 39th Annual Conference of the German Linguistic Society (DGfS), Saarbrücken, 8.-10.3.2017.

Haspelmath, M., 1999. Why is grammaticalization irreversible?. Linguistics 37 (6), 1043-1068.

Haspelmath, M., 2008. Creating economical morphosyntactic patterns in language change. In: Good, J. (Ed.), Language Universals and Language Change. Oxford University Press, Oxford, pp. 185-214

Hock, H.-H., 1991. Principles of Historical Linguistics, second ed. Mouton de Gruyter, Berlin, New York.

Hopper, P.J., Traugott, E.C., 2003. Grammaticalization, second ed. Cambridge University Press, Cambridge.

Kuryłowicz, J., 1947. La nature des proces dits analogiques. Acta Linguistica 5, 15-37.

Lass, R., 1994. Old English. A Historical Linguistic Companion. Cambridge University Press, Cambridge.

Lehmann, Ch, 2015. Thoughts on Grammaticalization, third ed. Language Science Press, Berlin.

Lindblom, B., 1998. Systemic constraints and adaptive change in the formation of sound structure. In: Hurford, J.R., Studdert-Kennedy, M., Knight, Ch (Eds.), Approaches to the Evolution of Language. Cambridge University Press, Cambridge, pp. 242-264.

Lühr, R., 1991. Die deutsche Determinansphrase aus historischer Sicht. Beitr. Gesch. Dtsch. Sprache Lit. 113, $195-211$.

Malchukov, A.L., 2004. Constraining nominalization: function/form competition. Linguistics 44 (5), 973-1009.

Paul, H., 1917. Deutsche Grammatik. Band II. Teil III: Flexionslehre. Niemeyer, Tübingen.

Seiler, H., 1989. A functional view on prototypes. Arbeiten des Kölner Universalien-Projekts (akup), Nr. 77. Institut für Linguistik, Universität zu Köln.

Szczepaniak, R., 2009. Grammatikalisierung im Deutschen. Narr, Tübingen.

Wegener, H., 2002. Aufbau von markierten Pluralklassen im Deutschen - eine Herausforderung für die Markiertheitstheorie. Folia Ling. 36, 261-295.

Zifonun, G., Hoffmann, L., Strecker, B., 1997. Grammatik der deutschen Sprache. Walter de Gruyter, Berlin, New York. 